\title{
Biological Control of Gom-chwi (Ligularia fischeri) Phytophthora Root Rot with Enterobacter asburiae ObRS-5 to Suppress Zoosporangia Formation and Zoospores Germination
}

\author{
Dayeon Kim, Sang Yeob Lee, Seong Ho Ahn, Ji Hee Han, and Jin Woo Park* \\ Division of Agricultural Microbiology, National Institute of Agricultural Sciences, Rural Development Administration, \\ Wanju 55365, Korea
}

(Received on November 29, 2019; Revised on March 31, 2020; Accepted on April 28, 2020)

Gom-chwi (Ligularia fischeri) is severely infected with Phytophthora drechsleri, the causal organism of Phytophthora root rot, an economically important crop disease that needs management throughout the cultivation period. In the present study, Phytophthora root rot was controlled by using bacterial isolates from rhizosphere soils collected from various plants and screened for antagonistic activity against $P$. drechsleri. A total of 172 bacterial strains were isolated, of which, 49 strains showed antagonistic activities by dual culture assay. In the seedling assay, six out of the 49 strains showed a predominant effect on suppressing $P$. drechsleri. Among the six strains, the ObRS-5 strain showed remarkable against $\boldsymbol{P}$. drechsleri when treated with seed dipping or soil drenching. The ObRS-5 strain was identified as Enterobacter asburiae based on $16 \mathrm{~S}$ ribosomal RNA gene sequences analysis. The bacterial cells of $E$. asburiae ObRS-5 significantly suppressed sporangium formation and zoospore germination in $P$. drechsleri by $87.4 \%$ and $66.7 \%$, respectively. In addition, culture filtrate of $E$. asburiae ObRS-5 also significantly inhibited sporangium formation and zoospore germination by $\mathbf{9 7 . 0} \%$ and $\mathbf{6 7 . 6 \%}$, respectively. Soil drenched bacterial cells, filtrate, and culture solution of $E$. asburiae ObRS-5 effectively suppressed Phytophthora root rot by $63.2 \%, 57.9 \%$, and $81.1 \%$, respectively. Thus, $E$.

\footnotetext{
*Corresponding author.

Phone) +82-63-238-3059, FAX) +82-63-238-3834

E-mail) jinwoopark@korea.kr

(c) This is an Open Access article distributed under the terms of the Creative Commons Attribution Non-Commercial License (http:// creativecommons.org/licenses/by-nc/4.0) which permits unrestricted noncommercial use, distribution, and reproduction in any medium, provided the original work is properly cited.
}

Articles can be freely viewed online at www.ppjonline.org. asburiae ObRS-5 could be used as a potential agent for the biological control of Phytophthora root rot infecting gom-chwi.

Keywords : antagonism, biological control, Enterobacter asburiae ObRS-5, Ligularia fischeri, Phytophthora drechsleri

Handling Editor : Youn-Sig Kwak

Ligularia fischeri, locally known as gom-chwi, is a perennial wild vegetable found in shady and humid environments of forest understories in Korea. It is an edible vegetable with high consumer preference because of its bitter taste and rich flavor (Cho and Kim, 2005). In the 1990s, the plant started being cultivated in greenhouses and forest fields in Gangwon-do, Gyeongsang-do, Jeollabuk-do, and Jeollanam-do (Rural Development Administration, 2018). Although the cultivation of gom-chwi plants in greenhouses has facilitated the supply of fresh products to consumers throughout the year, the environmental characteristics of greenhouses have promoted the occurrence of many plant diseases (Nam, 2001). It has been reported that various problems such as Phytophthora root rot, Sclerotium stem rot, and powdery mildew occur during cultivation in greenhouses with environmental characteristics that differ from the crop's native habitat, such as high temperature and low humidity (Korean Society of Plant Pathology, 2009; Kwon et al., 1999; Moon et al., 2015). Cultivation in greenhouses adversely affects gom-chwi growth because underground and above-ground temperatures are higher than that of the native habitat, and organic matter content is lower $(\sim 19-55$ $\mathrm{g} / \mathrm{kg}$ ) than that of the native habitat $(110 \mathrm{~g} / \mathrm{kg}$ ) (Kim et al., 2016; Rural Development Administration, 2018). 
One of the major biotic problems in gom-chwi cultivation is Phytophthora root rot caused by Phytophthora drechsleri. This fungal pathogen spreads quickly in the field through infected plants and wind-blown rain, as well as contaminated irrigation water, soil, or gravel substrates, making it difficult to control (Kwon et al., 1999). Many studies have been conducted on the use of microorganisms as biological control agents against plant diseases to increase agricultural productivity, as an alternative to chemical pesticides (Bhardwaj et al., 2014; Borriss, 2015; Fravel, 2005; Gupta et al., 2015). Generally, farmers and consumers prefer eco-friendly cultivation of gom-chwi. However, the use of microbial biocontrol agents is not available yet. Moreover, seedling production is difficult, and the cost of seedlings is higher than other crops because of the low germination rate. Therefore, only a few farmers are willing to plant seedlings every year, leading to a high prevalence of Phytophthora root rot caused by serial cultivation of gomchwi. In the last two years, some gom-chwi fields in Jeollado were infected by Phytophthora root rot at 24.1-43.1\% infection rate, leading to reduced yields; therefore, farmers replaced gom-chwi with other crops such as butterbur, Aralia elata and Capsicum annuum.

Many biocontrol agents can interfere with the growth and infection of phytopathogens inhabiting the plant rhizosphere (Doran and Zeiss, 2000; Kim et al., 1999; Liu et al., 2015; Ryan et al., 2008). Biocontrol agents use direct and indirect antagonistic and supportive mechanisms for achieving disease control. These mechanisms include antimicrobial activity, parasitic activity, space or nutrient competition, antibiotic production, and disease resistance induction. Another mechanism is the provision of biological fertilizer through phosphoric acid solubilization, nitrogen fixation, and plant growth-promoting hormone production (Haggag and Timmusk, 2008; Mahaffee and Backman, 1993; Park et al., 2010; Szczech and Shoda, 2006).

Studies have been conducted on the biological control of Phytophthora root rot using microorganisms. Paenibacillus polymyxa AC-1 strain, which effectively controls red pepper blight, has been commercialized in Korea. In addition, in Europe and the United States, Bacillus subtilis QST 713, Streptomyces lydicus WYEC 108, Trichoderma atroviride CHS 861, and Gliocladium virens GL-21 are already commercialized as biocontrol agents against Phytophthora disease (Elliott et al., 2009). These microorganisms produce various secondary metabolites and antibiotics that inhibit Phytophthora spp. and let the expression of defense-related genes increase in treated plants to which it is applied (Bae et al., 2016; Shahidi Bonjar et al., 2006; Shirzad et al., 2012). Trichoderma atroviride, which establishes in the plant root, changes the carbohydrate composition of the root exudates in order to control the disease by predominating rhizosphere colonization over Phytophthora cinnamomi and competing for space and nutrients (Macías-Rodríguez et al., 2018). Rhamnolipids and cyclic lipopeptides produced by Pseudomonas spp. can inhibit the formation of the zoosporangia membrane of Phytophthora spp. (De Bruijn et al., 2007; Maleki et al., 2011).

Biological control agents for the management of $P$. drechsleri have not yet been reported, indicating that biocontrol agents still need to be developed for the successful control of Phytophthora root rot of gom-chwi. The objectives of this study were to (1) isolate rhizobacteria from various plants, (2) describe a screening approach with in vitro and seedling bioassays by seed dipping and soil drenching treatments to select bacterial strains with antagonistic activities towards $P$. drechsleri, (3) investigate the suppression mechanisms of a selected bacterium, $E$. asburiae ObRS-5, on $P$. drechsleri, including effects on zoosporangia formation and zoospore germination in plants treated with ObRS-5 bacterial cells, filtrate and culture solution, and (4) evaluate the biocontrol efficacy of ObRS5 on Phytophthora root rot of gom-chwi in potted plants under glasshouse conditions.

\section{Materials and Methods}

Pathogen isolate and preparation of inoculum. The Phytophthora drechsleri Gcbs-5 strain was isolated from gomchwi in greenhouse fields in Geochang in Korea following Meszka and Michalecka (2016). It was then stored on a potato dextrose agar (PDA; Difco, Detroit, MI, USA) slant in the dark at $15^{\circ} \mathrm{C}$ (Kwon et al., 1999). Identification of $P$. drechsleri was done by comparing its cultural and morphological characteristics with descriptions published in the literature and by phylogenetic analysis (Rural Development Administration, National Institute of Agricultural Science and Technology, Plant Pathology Division, 2000).

Zoospores probably function as the primary inoculum for infecting gom-chwi plants (Biles et al., 1995), however, a major problem is production of the large quantities of similar-aged zoospores of $P$. drechsleri required for inoculation (Mansoori and Banihashemi, 1982) according to existing methods (Barash et al., 1965; Cother and Griffin 1973; Mehrotra 1970). Thus, the mycelium of $P$. drechsleri were used as a pathogen inoculum for seedling assay and tests on potted plants in the glasshouse. Forty grams of barley was added to $45 \mathrm{ml}$ of distilled water in a 11 Erlenmeyer flask and then it was autoclaved twice for $20 \mathrm{~min}$ at $121^{\circ} \mathrm{C}$. The flask was inoculated with five mycelial plugs 
(5 mm diameter) from a 5-day-old culture of $P$. drechsleri, that was incubated at $25^{\circ} \mathrm{C}$. The inoculated barley medium was shaken daily to break up particles so that the pathogen and medium were well mixed. For pathogen inoculation, a granule of $P$. drechsleri infected barley was attached to the upper part of gom-chwi roots (Pieterse et al., 1996).

Field sampling and isolation of rhizobacteria. Bacteria were isolated from the rhizosphere soil collected from seven kinds of plants: gom-chwies, strawberries, celeries, kales, red beets, chicories, and red lettuces from Damyang, Iksan, Milyang and Sunchang regions in Korea. A threegram soil sample was added to $27 \mathrm{ml}$ of sterilized distilled water and shaken at $180 \mathrm{rpm}$ and $28^{\circ} \mathrm{C}$, for $30 \mathrm{~min}$. Subsequently, $1 \mathrm{ml}$ suspension was taken and diluted to $9 \mathrm{ml}$ of sterilized distilled water, 5 times in a row, and $1 \mathrm{ml}$ of each final suspension was taken and spread onto tryptic soybean agar (TSA; Difco), 1/10 TSA and nutrient agar (Difco) medium. After incubation at $28^{\circ} \mathrm{C}$ for $48 \mathrm{~h}$, single colonies with different colors and shapes were isolated and stored at $-70^{\circ} \mathrm{C}$ in $20 \%$ glycerol.

Screening of antagonistic bacteria in vitro and in seedling assays in the glasshouse

Dual culture assay. Inhibition of mycelial growth of $P$. drechsleri in the bacterial isolates was tested by dual culture assay. The bacterial isolates were equidistantly streaked on the margins of the PDA plates and incubated at $28^{\circ} \mathrm{C}$ for $24 \mathrm{~h}$. Sterile distilled water was used for the control. The agar disc with $5 \mathrm{~mm}$ of $P$. drechsleri was placed at the center of the PDA plate and incubated at $25^{\circ} \mathrm{C}$ for 5 days. The growth inhibition length of mycelium was measured in order to screen the antagonistic bacterial strains against $P$. drechsleri, using the method of Idris et al. (2007).

Seedling assay. Forty-nine bacterial strains, resulting from dual culture assays, were evaluated for the suppression of Phytophthora root rot using gom-chwi seedlings. For the seed dipping treatment, $10^{8} \mathrm{cfu} / \mathrm{ml}\left(\mathrm{OD}_{600}=0.25\right)$ of bacterial suspension in $0.1 \%$ peptone water (Becton Dickinson Biosciences, San Jose, CA, USA) was prepared. The seeds (cv. Aram) were dipped in a bacterial suspension for $3 \mathrm{~h}$. For the pathogen-treated control (control) and pathogen non-treated control (mock), seeds were dipped in $0.1 \%$ peptone water without any bacterial treatment. The gomchwi seeds were sown on a 32-hole tray filled with soil (Green Soil, Seoul Bio, Eumseong, Korea). A set of 16 individual gom-chwi plants was used for each treatment. To introduce the pathogen inoculum, one granule of barley infected with $P$. drechsleri, as described above, was inoculat- ed on the upper part of the root of a 5-week-old gom-chwi after the soil was slightly removed. Pathogen non-treated control plants were mock-inoculated with a granule of noninfected barley (Maleki et al., 2011; Pieterse et al., 1996). All plants were irrigated regularly. The severity of diseased plants was evaluated 7 days after pathogen inoculation and the onset of symptoms. Disease severity (modified from Irabor and Mmbaga, 2017) was evaluated on a scale of 0-3 (Supplementary Table 1): 0 = no visible symptoms; 1 $=$ slightly diseased, $20 \%$ of total leaves were wilted with brownish lesions beginning to appear on the stem; $2=$ stem lesions extending to cotyledons or petioles and $50 \%$ of total leaves were wilted; and $3=$ entire plant diseased or dead.

Six bacterial strains from the seedling assays with seed dipping treatment were evaluated using gom-chwi plants using a soil drenching treatment. The bacterial strains were incubated in the tryptic soybean broth medium (TSB; Difco) at $28^{\circ} \mathrm{C}$ for $24 \mathrm{~h}$. The culture solutions of bacterial strains were adjusted to a concentration of $10^{8} \mathrm{cfu} / \mathrm{ml}\left(\mathrm{OD}_{600}\right.$ $=0.25$ ). Five-week-old gom-chwi seedlings growing in a 32-hole tray were drenched once with $15 \mathrm{ml}$ bacterial culture solution, and a set of 32 individual gom-chwi plants was used for each treatment. The control and mock-control were treated with $15 \mathrm{ml}$ of TSB medium. Pathogen inoculum was conducted as described above and, disease severity were also evaluated as described above. All experiment were repeated three times. The control efficacies indicate the differences in the disease incidence rates, as a percentage, of between bacterial treatments and untreated control, which was calculated by the method of Tsuda et al. (2016).

16S rRNA gene sequencing for the identification of the ObRS-5 strain. The total genomic DNA of the ObRS5 strain was extracted using a Genomic DNA Prep kit (Nanohelix, Daejeon, Korea) following the user manual. A 1,356-bp of 16S rRNA gene fragment was amplified from genomic DNA of strain ObRS-5 using the universal primers, 27F (forward) 5'-GAG TTT GMT CCT GGC TCA G-3' and 1492R (reverse) 5'- ACG GYT ACC TTG TTA CGA CTT-3' (Weisbrug et al., 1991). Amplification of the $16 \mathrm{~S}$ rRNA region was performed in a total volume of $25 \mu \mathrm{l}$ containing $50 \mathrm{ng}$ of DNA template, $0.25 \mu \mathrm{M}$ of each primer, $0.25 \mu \mathrm{M}$ of dNTP (Inclone, Daejeon, Korea), $2.5 \mu \mathrm{l}$ of $10 \times$ buffer (Inclone) and 1.25 U of Taq DNA polymerase (Inclone), and $1.25 \mu \mathrm{l}$ of $1.10 \mathrm{~g} / \mathrm{ml}$ of dimethyl sulphoxide (Sigma-Aldrich, St. Louis, MO, USA). The PCR mixture was first heated at $95^{\circ} \mathrm{C}$ for $5 \mathrm{~min}$, and 30 cycles were then performed at different temperatures: $95^{\circ} \mathrm{C}$ for $1 \mathrm{~min}$, $55^{\circ} \mathrm{C}$ for $1 \mathrm{~min}$, and $72^{\circ} \mathrm{C}$ for $1 \mathrm{~min} 30 \mathrm{~s}$. The reaction was finally incubated at $72^{\circ} \mathrm{C}$ for $10 \mathrm{~min}$. The fragment size of 
the amplified PCR products was confirmed by electrophoresis analysis, and afterward, sequencing was conducted by Genotech Co. (Daejeon, Korea). The raw sequences were aligned for a phylogenetic dendrogram, which was constructed using a neighbor-joining algorithm using MEGA software (ver. 6.06) and 1,000 replicates of bootstrapping (Felsenstein, 1985). The working reference sequences were downloaded using the EzBioCloud server at http://www. ezbiocloud.net/.

Antagonism of Enterobacter asburiae ObRS-5 against $P$. drechsleri

Effect on zoosporangium formation. The culture solution of the ObRS- 5 strain was adjusted to $1.0 \times 10^{8} \mathrm{cfu} / \mathrm{ml}$ $\left(\mathrm{OD}_{600}=0.25\right)$ and centrifuged at 8,000 rpm for $10 \mathrm{~min}$. The supernatant was then filter-sterilized using a $0.22 \mu \mathrm{m}$ syringe filter (Millipore, Billerica, MA, USA) for '(filtered) filtrate' or was autoclaved at $121^{\circ} \mathrm{C}$ for $15 \mathrm{~min}$ for 'sterilized filtrate'. The harvested cells were resuspended in $0.1 \%$ peptone water at a concentration of $1.0 \times 10^{8} \mathrm{cfu} / \mathrm{ml}\left(\mathrm{OD}_{600}\right.$ $=0.25)$. Mycelial discs of $P$. drechsleri from the peripheral growth of a 5-day-old culture on PDA were transferred to Petri dishes, containing $30 \mathrm{ml}$ of $10 \%(\mathrm{v} / \mathrm{v})$ clarified V8 medium with $0.3 \% \mathrm{CaCO}_{3}$, which were incubated at $25^{\circ} \mathrm{C}$ for 4 days (Lee et al., 2001). The medium was decanted and replaced by $30 \mathrm{ml}$ of bacterial cell suspension, culture solution, and filtrate of E. asburiae ObRS-5, with the sterile soil extracts at a ratio of 1:6 (v/v) (De Cock and Lévesque, 2004). Soil extracts were prepared as described by Mansoori and Banihashemi (1982). The control was treated with only sterile soil extracts, and the medium-treated control was treated with TSB and sterile soil extracts at a ratio of $1: 6(\mathrm{v} / \mathrm{v})$.

All plates were light-irradiated at $24 \mathrm{~h}$ per day at $25^{\circ} \mathrm{C}$ for 2 days. Microscopic observations (M205A, Leica, Jena, Germany) were conducted to count the number of zoosporangia formed (zoosporangia/5 $\mathrm{mm}^{2}$ ) from five random areas of the fungal growth, from each mycelial disc, because zoosporangium of $P$. drechsleri is non-caducous (Singh et al., 1992). Thus, the total number of zoospores was also investigated. In order to release the zoospores, all plates were treated at $-20^{\circ} \mathrm{C}$ for $25 \mathrm{~min}$ and treated at room temperature for $3 \mathrm{~h}$. The mycelium was filtered with sterile gauze and the released zoospores were counted using a hemocytometer (Incyto, Cheonan, Korea) under an optical microscope (DM2500, Leica).

Effect on zoospore germination. A zoospores suspension of $P$. drechsleri was prepared at a concentration of 1.0 $\times 10^{4}$ zoospores $/ \mathrm{ml}$ as described above. A prepared cell suspension, filtrate, or culture solution of ObRS-5 strain was mixed with the sterile soil extract at a ratio of $1: 1(\mathrm{v} /$ v) in a 96-well cell culture plate (SPL, Pocheon, Korea). Zoospore germination was observed under a microscope at 2-h intervals during incubation at $25^{\circ} \mathrm{C}$. The result of the cell suspension treatment was compared to the soil extracttreated control and the result of the remaining treatments were compared to the medium treated control.

Experiments on potted plants in a glasshouse. Gomchwi were sown in a 32-hole tray, they were grown for 4 weeks, and then gom-chwi plants were transplanted into plastic pots (10-cm-diameter) with soil. A set of 30 individual 12-week-old gom-chwi plants was used for tests under glasshouse conditions. Each plant was drenched once with $50 \mathrm{ml}$ of cell suspension, filtrate, sterilized filtrate, culture solution of $E$. asburiae ObRS-5 or TSB medium for control and mock-control treatments. Pathogen inoculum was treated with two granules of barley infected with $P$. drechsleri as described above. Disease severity were also evaluated as described above.

\section{Statistical analysis}

Data were statistically verified whether it follows a normal distribution or not by Levene test, and analyzed using analysis of variance (ANOVA) in R software (ver. 3.4.1), and the significance of each value was determined using Duncan's multiple range test $(P<0.05)$.

\section{Results}

The effect of bacterial isolates on mycelial growth in Phytophthora drechsleri. A total of 172 isolates were finally obtained from rhizosphere soils from diverse crops. Among these bacterial isolates, 26 isolates had 10-20\% and

Table 1. Number and percentage of bacterial isolates classified by degree of mycelial growth inhibition by dual culture assay against Phytophthora drechsleri

\begin{tabular}{lcc}
$\begin{array}{l}\text { Mycelial growth } \\
\text { inhibition rate }(\%)\end{array}$ & No. of isolates & $\begin{array}{c}\text { Percentage of } \\
\text { isolates }\end{array}$ \\
\hline$-^{\mathrm{a}}$ & 123 & 71.5 \\
$0-5$ & $10^{\mathrm{b}}$ & 5.8 \\
$5-10$ & $11^{\mathrm{b}}$ & 6.4 \\
$10-15$ & $14^{\mathrm{b}}$ & 8.1 \\
$15-20$ & 12 & 7.0 \\
$20-25$ & 1 & 0.6 \\
$25-30$ & 1 & 0.6 \\
\hline
\end{tabular}

a - , no inhibition observed.

${ }^{\mathrm{b}}$ Selected strains. 
144 isolates had less than $10 \%$ inhibition effect on mycelial growth in $P$. drechsleri (Table 1, Supplementary Fig. 1). In addition, only 2 isolates showed more than $20 \%$ mycelial inhibition rate, which was $1.2 \%$ of the total bacterial isolates. Thus, the evaluation with the seedling assay was carried out on 49 bacterial strains ( $28.5 \%$ of isolates) having a varied range of mycelial growth inhibition abilities.
Selection of bacterial strains and seedling assay in glasshouse. Among the 49 antagonistic strains, in the seed dipping treatment of six bacterial strains, RIR9, ObRS-5, ObRS-6, ObRS-10, ObRS-15, and HRS-20 were the most efficient in reducing disease severity in gom-chwi seedlings compared to the bacterially untreated control (Supplementary Table 2). The value of disease control efficacy (\%) of RIR9, ObRS-5, ObRS-6, ObRS-10, ObRS-15, and HRS-

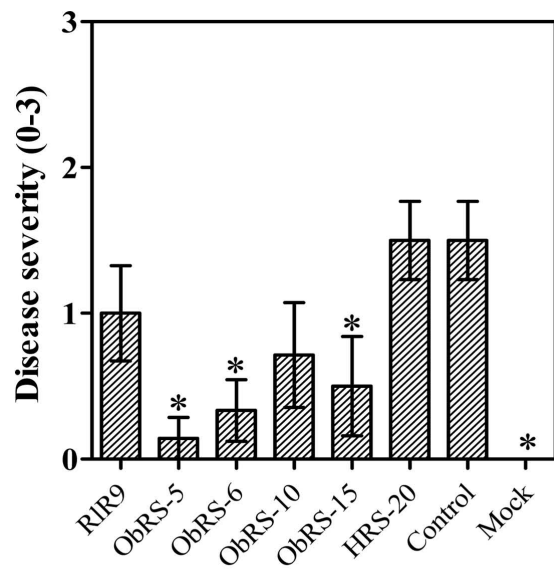

Treatments

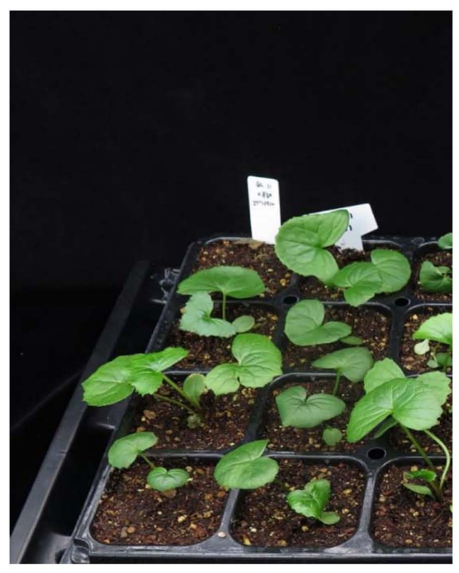

ObRS-5

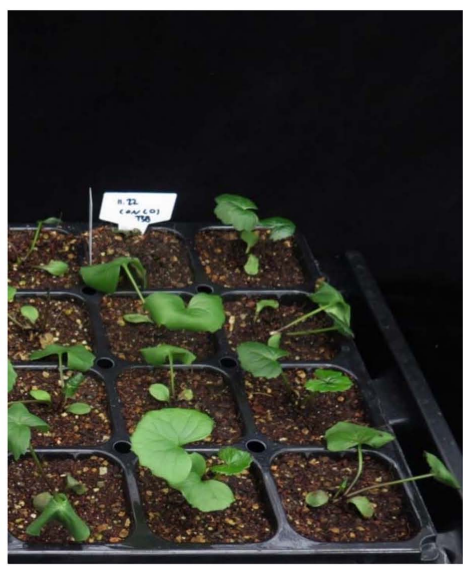

Control

Fig. 1. Biocontrol effect of soil drenching treatment of bacterial strains against Phytophthora drechsleri using 5-week-old gom-chwi seedlings. Values are means \pm standard errors of disease severity. Asterisk designate mean, which are significantly different from the mean of control, using Duncan's multiple range test $(* P<0.05)$.

A

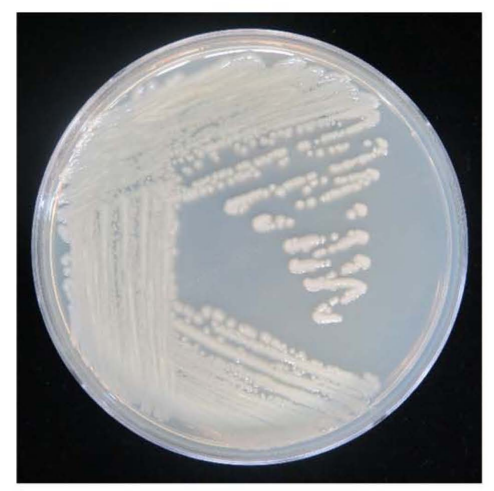

B

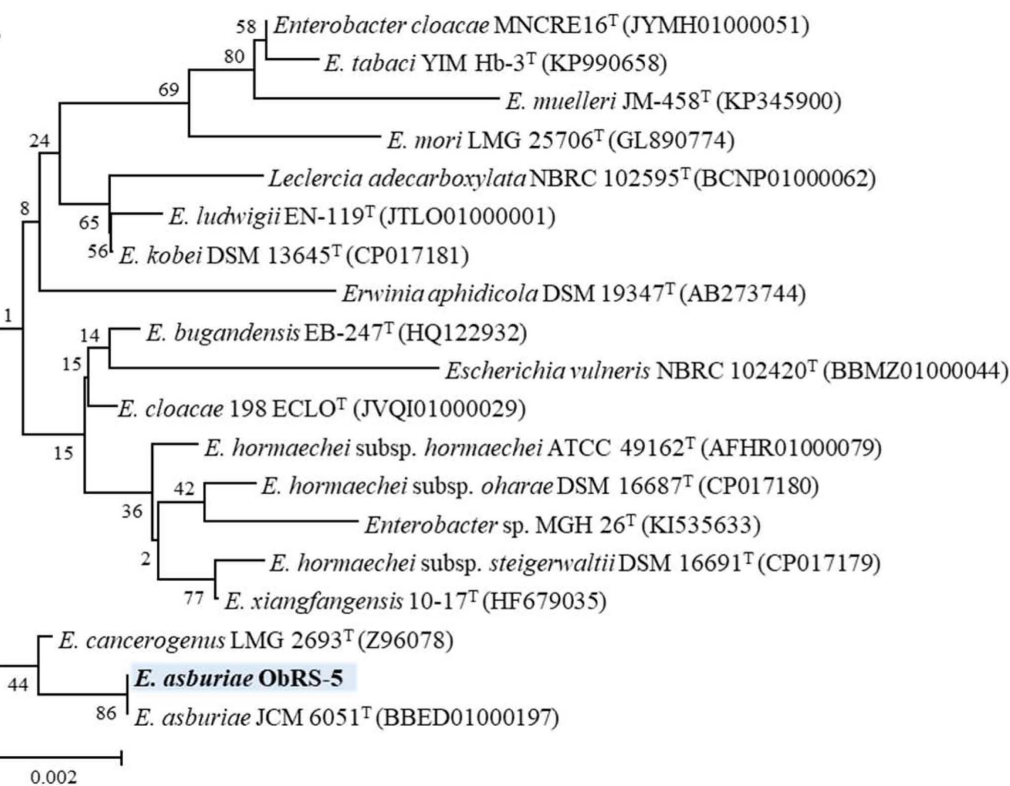

Fig. 2. Morphological and phylogenetic characterization of Enterobacter asburiae ObRS-5. (A) Colonies morphology on tryptic soybean agar medium and (B) phylogenetic dendrogram constructed from a comparative analysis of $16 \mathrm{~S}$ rRNA sequences showing the relationships between $E$. asburiae ObRS-5 and related species. Numbers at the branching points represent bootstrap values (>50\%) for 1,000 replicates. The scale bar indicates a distance of 0.002 substitutions per site. 
20 was $76.5,76.5,70.6,70.6,64.7$, and 58.8 , respectively. Whereas 22 strains showed a mildly suppressive effect with no significant differences compared to the control and 21 strains had no effect (0\%) (Supplementary Table 2). Thus, six bacterial strains were selected as potentially effective antagonists for further tests.

To assess whether these six bacterial strains have suppressive effects in sterilized soils or not, we performed to shoot plate assay (Supplementary Fig. 2A). In the shoot plate assay, seed dipping treatment of RIR9, ObRS-5, ObRS-6, ObRS-10, ObRS-15, and HRS-20 strains were showed means of infected rate at $15.6 \%, 12.5 \%, 31.3 \%$, $34.4 \%, 34.4 \%$, and $15.6 \%$, respectively, and those of ObRS-6, ObRS-10, and ObRS-15 strains have no suppressive effects compared to water-treated control. Whereas RIR9, ObRS-5, and HRS-20 showed control efficacy at $29.2 \%, 45.8 \%$, and $25 \%$, respectively (Supplementary Fig. 2B).

In the seedling assay with soil drenching treatment, three strains, ObRS-5, ObRS-6, and ObRS-15, showed significant control efficacies of $90.5 \%, 77.8 \%$, and $66.7 \%$, respectively (Fig. 1, Supplementary Fig. 3). Thus, among the

\section{A}
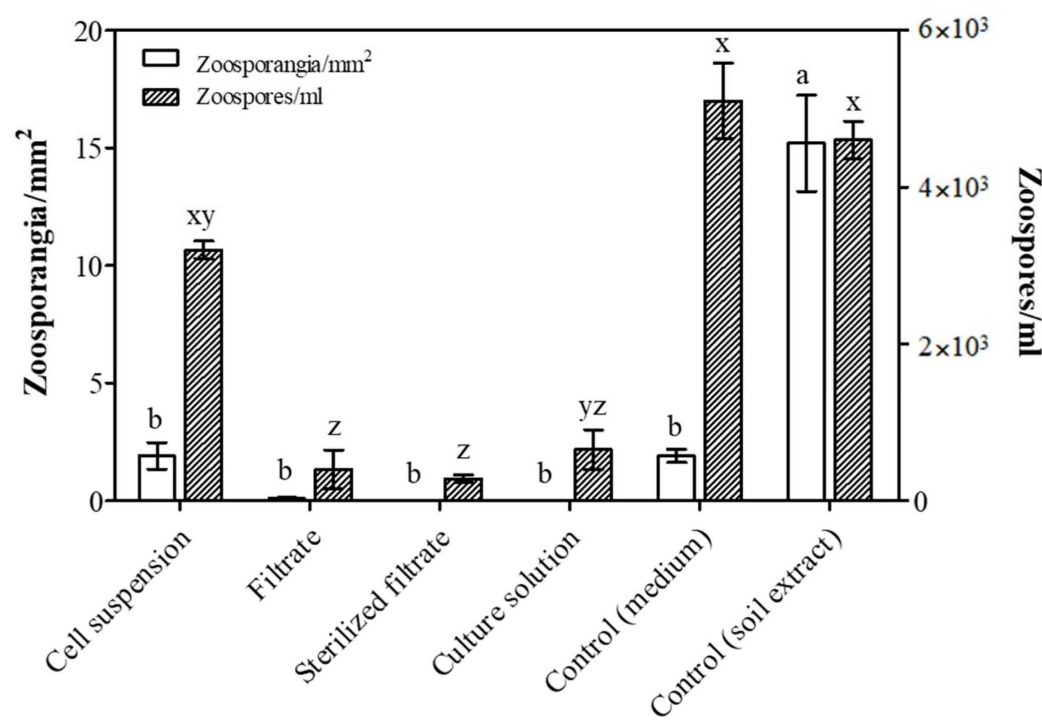

Treatment
B
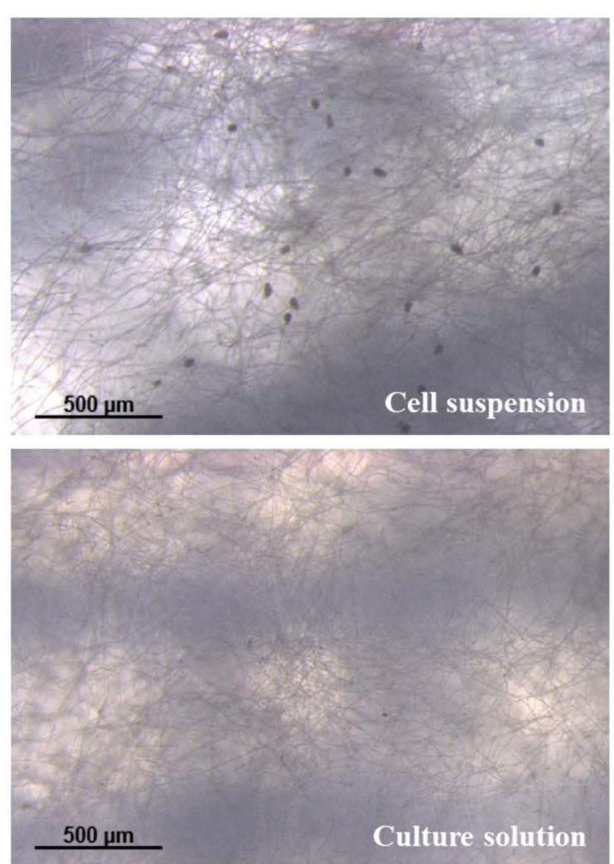
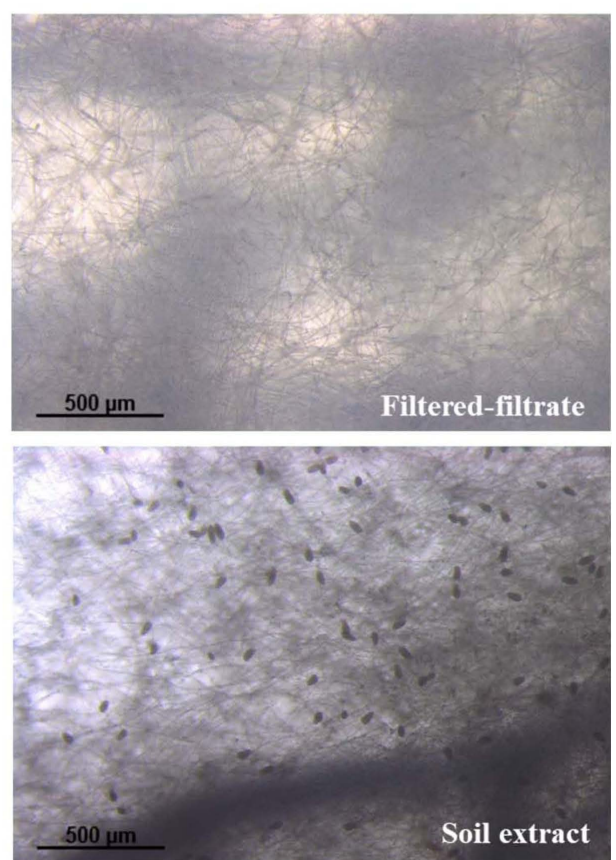

Fig. 3. Inhibition of zoosporangia formation of Phytophthora drechsleri by Enterobacter asburiae ObRS-5. (A) Number of zoosporangia per $\mathrm{mm}^{2}$ and zoospores per ml. (B) Inhibition on zoosporangia formation of treatment of ObRS- 5 cell suspension $\left(10^{8}\right.$ cells $\left./ \mathrm{ml}\right)$, filtered or sterilized filtrate, culture solution and control (treated with soil extract or medium). Values are means \pm standard error of the number of zoosporangia $\left(/ \mathrm{mm}^{2}\right)$ or zoospores $(/ \mathrm{ml})$. Lower cases mean, which are significantly different from the mean of control, using Duncan's multiple range test $(P$ $<0.05$ ). 
six antagonistic strains, the ObRS-5 strain was selected as potentially the most effective antagonist for further testing.

Identification of ObRS-5 strain with a biocontrol effect. Molecular phylogenetic analysis of the 16S rRNA sequences of ObRS-5 strain showed 99.9\% homology with Enterobacter asburiae JCM 6052, and the bootstrap value was $86 \%$ indicating that it belongs to the subcluster of $E$. asburiae (Fig. 2). Consequently, the ObRS-5 strain was finally identified as Enterobacter asburiae ObRS-5. The nucleotide sequences of ObRS-5 strain was submitted to Genbank as the accession number MT020371.

The antagonistic effect of ObRS-5 on $P$. drechsleri in vitro. Zoosporangia formation was reduced by treatment with cell suspension $(87.4 \%)$, filtrate $(97.0 \%)$, sterile filtrate (98.5\%) and culture solution (100\%) of E. asburiae ObRS5 (Fig. 3). As a result of counting the number of zoospores,

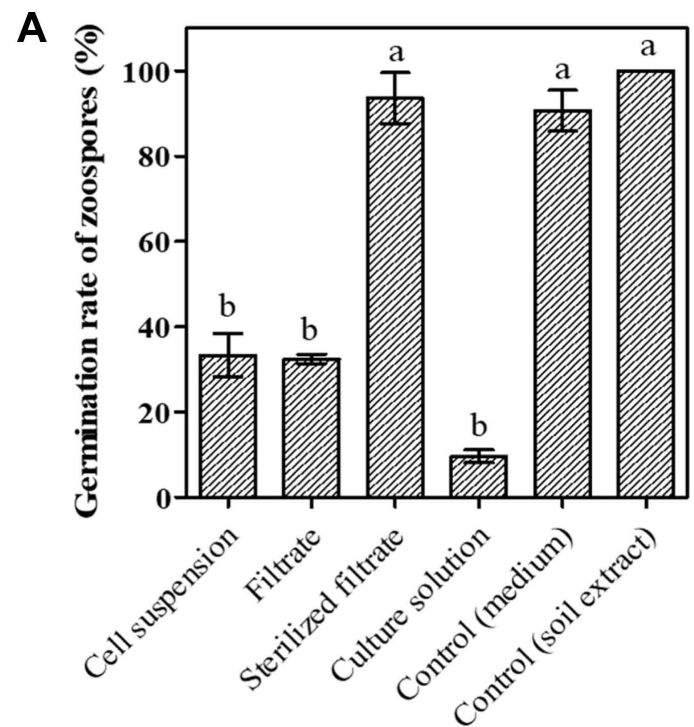

B

Treatments

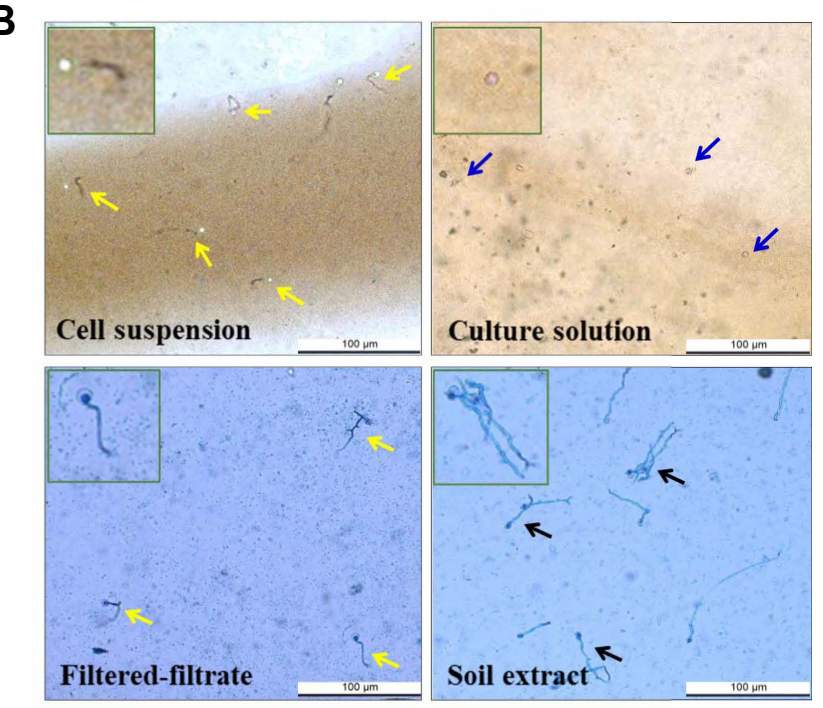

Fig. 4. Suppression of zoospores germination of Phytophthora drechsleri by Enterobacter asburiae ObRS-5. (A) Germination rate of zoospores (\%). (B) Inhibition effect on zoospores germination of treatment of ObRS-5 cell ( $10^{8}$ cells $\left./ \mathrm{ml}\right)$, culture solution, filtered or sterilized filtrate and control (treated with soil extract or medium). The arrows indicate that black is not suppressed, yellow is slightly suppressed and blue is significantly suppressed in zoospores germination. Values are means \pm standard error of zoospores germination rate $(\%)$. Letters mean, which are significantly different from the mean of control, using Duncan's multiple range test $(P<0.05)$.
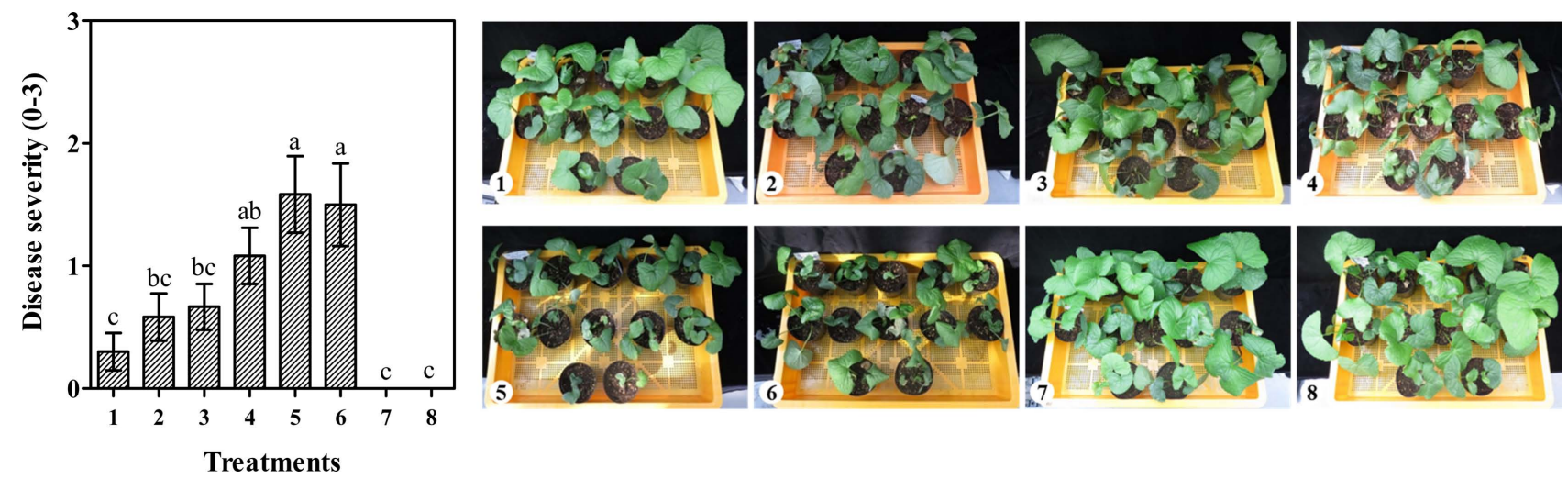

Fig. 5. Biocontrol effect of Enterobacter asburiae ObRS-5 on Phytophthora root rot in potted gom-chwi plants in the glasshouse. Gomchwi plants was soil drenched with 1, culture solution; 2, cell suspension; 3, filtrate and 4, sterilized-filtrate. As controls without $E$. asburiae ObRS-5 pathogen-inoculated control (5, water and 6, medium) and uninoculated control (7, water and 8, medium). Values are means \pm standard error of disease severity. Letters mean, which are significantly different from the mean of control, using Duncan's multiple range test $(P<0.05)$. 
the inhibition rate compared to the control was highest for the sterile filtrate $(94.6 \%)$, followed by the filtrate $(91.7 \%)$, culture solution (87.1\%) and cell suspension $(31.5 \%)$ of $E$. asburiae ObRS-5 (Fig. 3).

Meanwhile, in the zoospore germination, treatment of cell suspension, filtrate, sterile filtrate, and culture solution of E. asburiae ObRS-5 showed a germination rate of $33.3 \%, 32.4 \%, 93.6 \%$, and $9.6 \%$, respectively. The germination rate of sterile filtrate did not show significant differences in either medium treated control (90.6\%) or soil extract-treated control. There was also no statistical difference between the medium treated control and soil extracttreated control. As a result, the cell suspension, filtrate, and culture solution reduced zoospore germination at $66.7 \%$, $90.4 \%$, and 67.6\%, respectively (Fig. 4). In particular, $E$. asburiae ObRS-5 culture solution effectively suppressed zoospore germination. Therefore, E. asburiae ObRS-5 or its products might be involved in the inhibition of zoosporangia formation of $P$. drechsleri.

The biocontrol effect of ObRS-5 on Phytophthora root rot in plants in the glasshouse. The E. asburiae ObRS5 strain inhibited $P$. drechsleri infection in potted plants in the glasshouse. It was significantly antagonistic, and the control efficacies of gom-chwi plants were $80 \%$ (culture solution), 63.2\% (cell suspension), 55.6\% (filtrate) (Fig. 5). Gom-chwi plants treated with sterilized filtrate of E. asburiae ObRS-5 showed a disease severity of 1.08 , of which the pathogen-treated controls were 1.50 (medium) and 1.58 (water), and the results revealed that there was not significantly suppression effect, which is similar to the result of the in vitro experiment.

\section{Discussion}

In this study, we describe selection of potential bacterial biocontrol agent and investigation of selected bacterial character related biocontrol of Phytophthora root rot in gom-chwi. Phytophthora root rot caused by the oomycete pathogen Phytophthora drechsleri, has already reached a major problem of gom-chwi cultivation farms in Korea, thus it is necessary to develop agents which could work as effective biocontrol (Rural Development Administration, Agricultural Sciences Institute, 1991).

As a result of initial screening bacterial strains of disease suppression against $P$. drechsleri, among 172 isolates, 49 bacterial isolates with antagonistic behavior were selected by a dual culture assay. Especially, only two strains $(1.2 \%$ of the 172 strains) showed more than $20 \%$ mycelial inhibition rate. This result indicates that many of the isolates did not have antagonistic activity against $P$. drechsleri on agar (Table 1). In case of previous studies, Syed-Ab-Rahman et al. (2018) selected only $6 \%$ of the total isolates showing antagonism against Phytophthora spp., and Tjamos et al. (2004) reported that $12 \%$ of the isolates produced antifungal compounds in dual cultures against fungal phytopathogens. Although the bacterial strain showed the strongest antagonistic action against fungal pathogens on the agar medium, antibiotic activity was not always a constant feature for good disease control efficacy in fields (Tjamos et al., 2004).

Dual culture techniques on agar plates have commonly been used as a useful screening method (Schroth and Hancock, 1982). However, this screening might be limited to only investigating antagonistic ability on agar and it cannot select biocontrol agents that provide disease control by other mode of action, such as hyperparasitism/predation, lytic enzymes, and niche competition (Bakker et al., 2003; Pang et al., 2009; Pliego et al., 2011). On the other hand, numerous environmental factors, which were not considered in the screening steps, could disturb the microbial control efficacy in field, such as soil temperature, humidity, and soil microbial composition (Kloepper and Schroth, 1981).

Thus, for successful selection of suitable strains for disease control in field conditions, we conducted repetitive bioassays in host plants by using strains having varied antagonistic ranges in the microbial screening steps. Among these 49 isolates, 6 isolates were initially selected (Fig. 1). Among these six bacterial strains, HRS-20 strain had a significant effect by seed dipping, but, had no effect on Phytophthora root rot by soil drenching. The ObRS-6 and ObRS-15 strains also showed significant results with control efficacies of $77.8 \%$ and $52.4 \%$, respectively, in the seedling assay. However, the most effective strain, ObRS5 , reduced the percentage of disease severity by $90.5 \%$ with soil drenching as well as by $76.5 \%$ with the seed dipping treatment compared to the untreated control $(P<0.05)$. Finally ObRS- 5 strain was finally selected using repeated experiments, which predominantly reduced Phytophthora root rot and showed a control efficacy (Fig. 1).

In all bio-assays conducted in this study, in ObRS-5 strain treated gom-chwi plants, control effect of the soil drenching treatment $(90.5 \%)$ was better than the seed dipping method (76.5\%) or the seed dipping applied for sterilized soil (shoot plate assay, 45.8\%). Although there was a solely control effect by treatment with the ObRS-5 strain alone, it might underline that the higher effect by soil drenching is due to the complex interaction of microbiota in the root zone of the plant (Kim et al., 2019). Thus, the soil drenching could have been more effective than other 
methods because the isolation sources of the strains were rhizosphere soil of crops. Therefore, further research is needed to determine how the soil drenched strains can defend against pathogen invasion, interact with native microbes and react to root exudate in the rhizosphere of plants (Pascale et al., 2020).

Many of previous studies have demonstrated that the interaction of seeds and microorganisms improves the biological stress tolerance of plants (Kim et al., 2015; Mahmood et al., 2016; Nelson et al., 1986; Nelson, 2018). When seeds are treated with Enterobacter cloacae, the strain binds the mycelium of Pythium spp. so as to inhibit the growth of the pathogen (Nelson et al., 1986). Bacillus spp. also have a control effect on seed infectious plant diseases (Kim et al., 2015). There has been no report on the control effect of $E$. asburiae on Phytophthora spp.; however, the taxonomic position of E. asburiae ObRS-5 supports its plant disease control capacity. During a control study using Enterobacter spp., lipopolysaccharides of $E$. asburiae RS83 was reported to induce early stages of plant defense enzymes against lettuce bacterial blight (Jetiyanon and Plianbangchang, 2013). The E. cloacae strain was reported to effectively control Pythium disease and Fusarium blight through chitinolytic activity (Chernin et al., 1995; Jetiyanon, 2015), and the $E$. aerogenes strain is known to control Phytophthora root rot by colonizing the plant rhizosphere by secreting antibiotics such as hydroxamate, siderophore, volatile and nonvolatile antagonist (Berner et al., 1988; Utkhede, 1986).

A striking feature of Phytophthora spp. is that it produces numerous zoosporangia and zoospores, which rapidly result in plant infection (Erwin and Ribeiro, 1996). Thus, the control of Phytophthora root rot needs to effectively target the zoosporangia and zoospores. Treatment with cell suspension, filtrate, sterile filtrate, and culture solution of E. asburiae ObRS-5 resulted in inhibition of zoosporangia formation and zoospores germination (Figs. 3 and 4). Thus, E. asburiae ObRS-5 strain or its products might be involved in the suppression of reproduction and growth of $P$. drechsleri. Among these treatments, only sterile filtrate did not show a statistically significant difference to the control, which might be influenced of heat denaturation of yetknown, active compounds in culture filtrate. Meanwhile, in the medium treatment, the zoosporangia formation seemed to be inhibited $(87.6 \%)$. However, as the total number of zoospores was similar to the soil extract-treated control, it was thought that the medium might promote the release of zoospores from zoosporangia, and hollow zoosporangia were not counted (Fig. 3).

Similarly to the above, in the result of the pot plant experiment, gom-chwi plants treated with cell suspension, filtrate, and culture solution of E. asburiae ObRS-5 effectively suppressed the $P$. drechsleri infection with a biocontrol efficacy of $57.9-81.1 \%$. The action of suppression of zoosporangia formation and zoospore germination by $E$. asburiae ObRS-5 might be an important contributor to the suppression of Phytophthora root rot in gom-chwi. Hence, the use of E. asburiae ObRS-5 as a biocontrol agent should be promoted in gom-chwi cultivation.

\section{Acknowledgments}

This research was supported by the Rural Development Administration (Project No. PJ01259502), Republic of Korea.

\section{Electronic Supplementary Material}

Supplementary materials are available at The Plant Pathology Journal website (http://www.ppjonline.org/).

\section{References}

Bae, S.-J., Mohanta, T. K., Chung, J. Y., Ryu, M., Park, G., Shim, S., Hong, S.-B., Seo, H., Bae, D.-W., Bae, I., Kim, J.-J. and Bae, H. 2016. Trichoderma metabolites as biological control agents against Phytophthora pathogens. Biol. Control 92:128138.

Bakker, P. A. H. M., Ran, L. X., Pieterse, C. M. J. and van Loon, L. C. 2003. Understanding the involvement of rhizobacteriamediated induction of systemic resistance in biocontrol of plant diseases. Can. J. Plant Pathol. 25:5-9.

Barash, I., Klisiewicz, J. M. and Kosuge, T. 1965. Utilization of carbon compounds by zoospores of Phytophthora drechsleri and their effect on motility and germination. Phytopathology 55:1257-1261.

Berner, I., Konetschny-Rapp, S., Jung, G. and Winkelmann, G. 1988. Characterization of ferrioxamine $\mathrm{E}$ as the principal siderophore of Erwinia herbicola (Enterobacter agglomerans). Biol. Met. 1:51-56.

Bhardwaj, D., Ansari, M. W., Sahoo, R. K. and Tuteja, N. 2014. Biofertilizers function as key player in sustainable agriculture by improving soil fertility, plant tolerance and crop productivity. Microb. Cell Fact. 13:66.

Biles, C. L., Bruton, B. D., Wall, M. M. and Rivas, M. 1995. Phytophthora capsici zoospore infection of pepper fruit in various physical environments. Proc. Okla. Acad. Sci. 75:1-5.

Borriss, R. 2015. Bacillus, a plant-beneficial bacterium. In: Principles of plant-microbe interactions: microbes for sustainable agriculture, ed. by B. Lugtenberg, pp. 379-391. Springer, Cham, Switzerland.

Chernin, L., Ismailov, Z., Haran, S. and Chet, I. 1995. Chitinolytic Enterobacter agglomerans antagonistic to fungal plant pathogens. Appl. Environ. Microbiol. 61:1720-1726. 
Cho, S.-D. and Kim, G.-H. 2005. Food product development and quality characteristics of Ligularia fischeri for food resources. Korean J. Food Preserv. 12:43-47 (in Korean).

Cother, E. J. and Griffin, D. M. 1973. The role of alternative hosts in survival of Phytophthora drechsleri. Aust. J. Biol. Sci. 26:1109-1113.

De Bruijn, I., de Kock, M. J. D., Yang, M., de Waard, P., van Beek, T. A. and Raaijmakers, J. M. 2007. Genome-based discovery, structure prediction and functional analysis of cyclic lipopeptide antibiotics in Pseudomonas species. Mol. Microbiol. 63:417-428.

De Cock, A. W. A. M. and Lévesque, C. A. 2004. New species of Pythium and Phytophthora. Stud. Mycol. 50:481-487.

Doran, J. W. and Zeiss, M. R. 2000. Soil health and sustainability: managing the biotic component of soil quality. Appl. Soil Ecol. 15:3-11.

Elliott, M., Shamoun, S. F., Sumampong, G., James, D., Masri, S. and Varga, A. 2009. Evaluation of several commercial biocontrol products on European and North American populations of Phytophthora ramorum. Biocontrol Sci. Technol. 19:1007-1021.

Erwin, D. C. and Ribeiro, O. K. 1996. Phytophthora diseases worldwide. American Phytopathological Society, St. Paul, MN, USA. 562 pp.

Felsenstein, J. 1985. Confidence limits on phylogenies: an approach using the bootstrap. Evolution 39:783-791.

Fravel, D. R. 2005. Commercialization and implementation of biocontrol. Annu. Rev. Phytopathol. 43:337-359.

Gupta, G., Parihar, S. S., Ahirwar, N. K., Snehi, S. K. and Singh, V. 2015. Plant growth promoting rhizobacteria (PGPR): current and future prospects for development of sustainable agriculture. J. Microb. Biochem. Technol. 7:96-102.

Haggag, W. M. and Timmusk, S. 2008. Colonization of peanut roots by biofilm-forming Paenibacillus polymyxa initiates biocontrol against crown rot disease. J. Appl. Microbiol. 104:961-969.

Idris, H. A., Labuschagne, N. and Korsten, L. 2007. Screening rhizobacteria for biological control of Fusarium root and crown rot of sorghum in Ethiopia. Biol. Control 40:97-106.

Irabor, A. and Mmbaga, M. T. 2017. Evaluation of selected bacterial endophytes for biocontrol potential against phytophthora blight of bell pepper (Capsicum annuum L.). J. Plant Pathol. Microbiol. 8:424.

Jetiyanon, K. 2015. Multiple mechanisms of Enterobacter asburiae strain RS83 for plant growth enhancement. Songklanakarin J. Sci. Technol. 37:29-36.

Jetiyanon, K. and Plianbangchang, P. 2013. Lipopolysaccharide of Enterobacter asburiae strain RS83: a bacterial determinant for induction of early defensive enzymes in Lactuca sativa against soft rot disease. Biol. Control 67:301-307.

Kim, D., Lee, S. Y., Ahn, S. H., Han, J. H. and Park, J. W. 2019. Biocontrol effect on Phytophthora root rot and changes in rhizosphere bacterial communities in Ligularia fischeri by Enterobacter asburiae ObRS-5. Korean J. Pestic. Sci. 23:348-
357 (in Korean).

Kim, J.-S., Kwon, S.-W., Lee, S.-J., Jung, B.-G., Song, J.-K., Go, S.-J. and Ryu, J.-C. 1999. Analysis of microbial community structure in soil and crop root system: I. Analysis of bacterial community structure in the soil and root system of red pepper and tomato. J. Korean Soc. Soil Sci. Fert. 32:319-325 (in Korean).

Kim, Y., Choi, B., Kim, S., Moon, Y., Kim, K., Shin, D., Kim, D. and Hong, D. 2016. Investigation of the injury cause by the continuous cropping of Ligularia fischeri Turcz in Gangwon area. Korean J. Hortic. Sci. Technol. 34 Suppl. I:128.

Kim, Y.-K., Hong, S.-J., Shim, C.-K., Kim, M.-J., Park, J.-H., Han, E.-J., Park, J.-W., Park, S.-H., Jee, H.-J. and Kim, S.-C. 2015. Effect of extract and bacteria from Korean fermented foods on the control of sesame seed-borne fungal disease. Res. Plant Dis. 21:297-308 (in Korean).

Kloepper, J. W. and Schroth, M. N. 1981. Relationship of in vitro antibiosis of plant growth-promoting rhizobacteria to plant growth and the displacement of root microflora. Phytopathology 71:1020-1024.

Korean Society of Plant Pathology. 2009. List of plant diseases in Korea. 5th ed. The Korean Society of Plant Pathology, Suwon, Korea. 853 pp. (in Korean).

Kwon, S. B., Jee, H. J., Bang, S. B., Lee, K. K. and Hong, C. K. 1999. Phytophthora root rot of Ligularia fishcheri caused by $P$. drechsleri. Plant Dis. Agric. 5:58-60 (in Korean).

Lee, Y.-H., Jee, H.-J., Cha, K.-H., Ko, S.-J. and Park, K.-B. 2001. Occurrence of Phytophthora root rot on kiwifruit in Korea. Plant Pathol. J. 17:154-158.

Liu, C., Sheng, J., Chen, L., Zheng, Y., Lee, D. Y., Yang, Y., Xu, M. and Shen, L. 2015. Biocontrol activity of Bacillus subtilis isolated from agaricus bisporus mushroom compost against pathogenic fungi. J. Agric. Food Chem. 63:6009-6018.

Macías-Rodríguez, L., Guzmán-Gómez, A., García-Juárez, P. and Contreras-Cornejo, H. A. 2018. Trichoderma atroviride promotes tomato development and alters the root exudation of carbohydrates, which stimulates fungal growth and the biocontrol of the phytopathogen Phytophthora cinnamomi in a tripartite interaction system. FEMS Microbiol. Ecol. 94:fiy137.

Mahaffee, W. F. and Backman, P. A. 1993. Effects of seed factors on spermosphere and rhizosphere colonization of cotton by Bacillus subtilis GB03. Phytopathology 83:1120-1125.

Mahmood, A., Turgay, O. C., Farooq, M. and Hayat, R. 2016. Seed biopriming with plant growth promoting rhizobacteria: a review. FEMS Microbiol. Ecol. 92:fiw112.

Mansoori, B. and Banihashemi, Z. 1982. Evaluating cucurbit seedling resistance to Phytophthora drechsleri. Plant Dis. 66:373-376.

Maleki M., Mokhtarnejad, L. and Mostafaee, S. 2011. Screening of rhizobacteria for biological control of cucumber root and crown rot caused by Phytophthora drechsleri. Plant Pathol. J. 27:78-84.

Mehrotra, R. S. 1970. Techniques for demonstrating accumula- 
tion of zoospores of Phytophthora species on roots in soil. Can. J. Bot. 48:879-882.

Meszka, B. and Michalecka, M. 2016. Identification of Phytophthora spp. isolated from plants and soil samples on strawberry plantations in Poland. J. Plant Dis. Prot. 123:29-36.

Moon, Y.-G., Kim, S.-W., Choi, J.-K., Kwon, S.-B., Shim, H.-S., Ju, H.-J. and Choi, I.-Y. 2015. Stem rot on Ligularia fischeri caused by Sclerotium rolfsii in Korea. Res. Plant Dis. 21:3639 (in Korean).

Nam, K. U. 2001. Development of control measures and ecology against main plants disease in greenhouse. Prot. Hortic. 14:23-29 (in Korean).

Nelson, E. B. 2018. The seed microbiome: origins, interactions, and impacts. Plant Soil. 422:7-34.

Nelson, E. B., Chao, W.-L., Norton, J. M., Nash, G. T. and Harman, G. E. 1986. Attachment of Enterobacter cloacae to hyphae of Pythium ultimum: possible role in the biological control of Pythium preemergenee damping-off. Phytopatholgy 76:327-335.

Pang, Y., Liu, X., Ma, Y., Chernin, L., Berg, G. and Gao, K. 2009. Induction of systemic resistance, root colonisation and biocontrol activities of the rhizospheric strain of Serratia plymuthica are dependent on $\mathrm{N}$-acyl homoserine lactones. Eur. J. Plant Pathol. 124:261-268.

Park, J.-W., Jahaggirdar, S., Cho, Y.-E., Park, K.-S., Lee, S.-H. and Park, K.-S. 2010. Evaluation of Bacillus subtilis native strains for plant growth promotion and induced systemic resistance in tomato and red-pepper. Korean J. Pestic. Sci. 14:407-414.

Pascale, A., Proietti, S., Pantelides, I. S. and Stringlis, I. A. 2020. Modulation of the root microbiome by plant molecules: the basis for targeted disease suppression and plant growth promotion. Front. Plant Sci. 10:1741.

Pieterse, C. M., van Wees, S. C., Hoffland, E., van Pelt, J. A. and van Loon, L. C. 1996. Systemic resistance in Arabidopsis induced by biocontrol bacteria is independent of salicylic acid accumulation and pathogenesis-related gene expression. Plant Cell 8:1225-1237.

Pliego, C., Ramos, C., de Vicente, A. and Cazorla, F. M. 2011. Screening for candidate bacterial biocontrol agents against soilborne fungal plant pathogens. Plant Soil. 340:505-520.

Rural Development Administration. 2018. Assistant agricultural technology 60. Wild vegetable. 4th ed. Rural Development Administration, Jeonju, Korea. 441 pp. (in Korean).

Rural Development Administration, Agricultural Sciences Institute . 1991. Compendium of medicinal plant diseases with colour plates. Rural Development Administration, Suwon, Korea. 210 pp. (in Korean).

Rural Development Administration, National Institute of Agricultural Science and Technology, Plant Pathology Division . 2000. Phytophthora diseases in Korea. Rural Development Administration, Suwon, Korea. 226 pp. (in Korean).

Ryan, R. P., Germaine, K., Franks, A., Ryan, D. J. and Dowling, D. N. 2008. Bacterial endophytes: recent developments and applications. FEMS Microbiol. Lett. 278:1-9.

Schroth, M. N. and Hancock, J. G. 1982. Disease-suppressive soil and root-colonizing bacteria. Science 216:1376-1381.

Shahidi Bonjar, G. H., Barkhordar, B., Pakgohar, N., Aghighi, S., Biglary, S., Rashid Farrokhi, P., Aminaii, M., Mahdavi, M. J. and Aghelizadeh, A. 2006. Biological control of Phytophthora drechsleri Tucker, the causal agent of pistachio gummosis, under greenhouse conditions by use of Actinomycetes. Plant Pathol. J. 5:20-23.

Shirzad, A., Fallahzadeh-Mamaghani, V. and Pazhouhandeh, M. 2012. antagonistic potential of fluorescent Pseudomonads and control of crown and root rot of cucumber caused by Phythophtora drechsleri. Plant Pathol. J. 28:1-9.

Singh, U. P., Chauhan, V. B., Wagner, K. G. and Kumar, A. 1992. Effect of ajoene, a compound derived from garlic (Allium sativum), on Phytophthora drechsleri f. sp. Cajani. Mycologia 84:105-108.

Syed-Ab-Rahman, S. F., Carvalhais, L. C., Chua, E., Xiao, Y., Wass, T. J. and Schenk, P. M. 2018. Identification of soil bacterial isolates suppressing different Phytophthora spp. and promoting plant growth. Front. Plant Sci. 9:1052.

Szczech, M. and Shoda, M. 2006. The effect of mode of application of Bacillus subtilis RB14-C on its efficacy as a biocontrol agent against Rhizoctonia solani. J. Phytopathol. 154:370377.

Tjamos, E. C., Tsitsigiannis, D. I., Tjamos, S. E., Antoniou, P. P. and Katinakis, P. 2004. Selection and screening of endorhizosphere bacteria from solarized soils as biocontrol agents against Verticillium dahliae of solanaceous hosts. Eur. J. Plant Pathol. 110:35-44.

Tsuda, K., Tsuji, G., Higashiyama, M., Ogiyama, H., Umemura, K., Mitomi, M., Kubo, Y. and Kosaka, Y. 2016. Biological control of bacterial soft rot in Chinese cabbage by Lactobacillus plantarum strain BY under field conditions. Biol. Control 100:63-69.

Utkhede, R. S. 1986. Biology and control of apple crown rot caused by Phytophthora cactorum: a review. Phytoprotection 67:1-13. 